\title{
The impact of the Circle of Concerned African Women Theologians: French zone on church and African theology issues
}

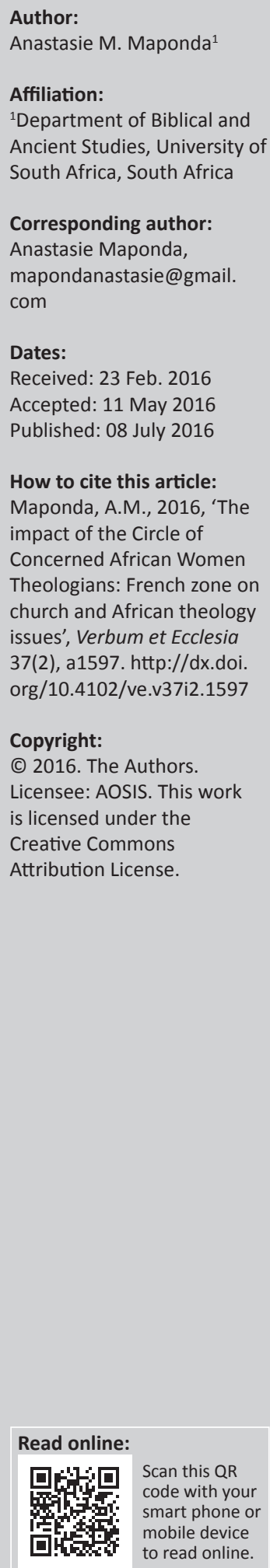

\begin{abstract}
We can understand that the Circle must work on two dimensions to provide a future for new woman theology in Africa. The first dimension is based on the intuitive fundamental and innovative sense of a woman from Ghana, Mercy Amba Oduyoye, that leads to the creation of the Circle: she impulsed the idea that women should make their own theology from their dailylife experiences and their subjectivity as women, in order to think on faith and Gospel in a different way. It is necessary to question that intuitive sense. The second dimension aims to revisit the great personalities of African woman theologians of the Circle. What are the essential points of their research? How has the research changed African theology? I particularly think of Musimbi Kanyoro, Nyambura Njoroge and Musa Dubé in the Africa English zone and Helene Yinda, Liz Vuadi, Kasa Dovi and Bernadette Mbuyi Beya in Africa French zone. The essence of their thinking is still actual and that is why they are good enough to project in to the future.

Intradisciplinary and/or interdisciplinary implications: This article presents the history of the Circle of Concerned African Women Theologians from creation to now. Issues related to traditional culture, gender and sexual-based violence, gender-based injustice, and HIV and AIDS are discussed under different approaches such as the biblical approach, hermeneutical approach, ethical approach, historical approach and practical approach. The impact of African Women Theologians speaking French will be particularly highlighted.
\end{abstract}

\section{Context of this article: Africa French zone experience}

This article describes the impact of the Circle of Concerned African Women Theologians - French zone from beginning to now. Looking for what the Circle of Concerned African Woman Theologians has brought into African theology, four dynamics should be highlighted.

The first dynamic is that theology has been seen from women's personal stories and way of life and those elements became a fertile resource in their fight today.

The second dynamic removes the mystification side of scientific theology and its demands in order to provide new approaches opened to every level of the society; then emerges people's theology based on everyday life realities.

The third dynamic shows the importance of culture and symbolic references as framework for interpreting the Word of God.

The fourth dynamic suggests a wide panorama on practical fights in society, such as the fight against HIV which becomes the symbol of the commitment of women theologians in Africa.

Except for the four dynamics presented above, relevant questions on the future of the Circle are mentioned. Two fundamental points of thinking are suggested to value the way theology is done by the new generation of African women theologians.

\section{Making theology from individual stories}

Under the impulsion of Mercy Oduyoye, the Circle of Concerned African Woman Theologians was created and extended with a new philosophy based on women's daily-life stories. Mercy Oduyoye presents her method: 'I have organized my narrative in three cycles of interlocking circles of stories ...' (Oduyoye 1995:13-16). In fact, the idea is to listen to what women, especially women theologians, have endured and experienced in the society and churches first as women and second 
as theologians. This way of doing unveils a well-hidden truth: women, considered as a social category, are marginalised in debates and choices on the future of the peoples and African countries; in addition, women are reduced to accessories as concern future orientations. In political and economic fields, in-cultural spheres and social responsibility, there is a hegemonic masculinity in such a way that being a woman means nothing. Mercy Oduyoye (1995) argues:

We recall history and analyze culture in order to understand how we got where we are and to see where we are heading: however, where we actually go depends on what we decide to do, or else we cease to be morally responsible agents. It is the woman who sleeps by fire of gender discrimination in the modern sectors of our economy, and it is the women in the home who knows how hot that fire is. If women are prepared to show their pain openly and articulate their vision for a more just and a more participatory and inclusive society, then perhaps we can begin to reshape the attitudes of society as a whole. (p. 73)

At the level of religion, the same hegemonic masculinity can be seen, as she adds:

Even more obvious is the fact that more women than men are clients of the divinities of the cults. In The African-instituted churches women are most visible in the structures of authority. However even here traditional taboos still exclude women, including women founders of the churches, from sacramental roles. (Oduyoye \& Kanyoro 1992:10)

What hurts the most is that, even in churches, women's situations are not different. Sometimes, it is worse: faith communities develop a vision and ideas on women that make them inferior and excluded from theological, educational and organisational responsibilities in the church; all this because some biblical passages are interpreted in a biased and falsified manner. As Mercy Oduyoye says: 'saying that God is male does not make the male god' (Oduyoye 1995:172). Thus, the theology of the Circle started from stories in order to identify, through women injustice, theological drifts and mental lies so that women can have a speech that matters. Therefore, it was necessary to read again biblical texts, not only with eyes but with the heart and woman awareness. So they got conscious of the feminine side of God and of all the values only women can be sensitive of (Oduyoye 1995:124-125). In Africa, this revelation became a new revolution; the fight has been possible thanks to a woman of faith and greatness: Mercy Amba Oduyoye, woman theologian from Ghana.

\section{Demystify the scientific approach of the Holy Scriptures}

Before the Circle of Concerned African Women Theologians could speak aloud on women issues, African theology institutions pretended to be 'scientific' institutions where the Bible is read in a very serious manner, through very skilful theories: historic-critical approach, structural-hermeneutical approach, psychoanalytic-materialistic approach and so on. All those approaches hide the fact that the Word of God is firstof-all a word of life; it is a shared word, a word for an existential conversion with values of love, mercy, generosity and sharing.
Without contesting the importance of solid theological training, in order to avoid the rise of dictatorial ignorance and the male exigence to maintain women in low educational levels, attitudes that Helene Yinda strongly denounces (Yinda \& Kä Mana 2005:19), the Circle insisted on contextual Bible studies and community Bible reading in churches, with themes focused on real problems, especially those faced by women in church and in the society. For this reason, Bernadette Mbuyi Beya declares in her speech on the impact of women in peacebuilding culture during the Assembly of Religious Sisters in Nairobi on November 2010, that women theologians make theology through their social experiences, cultures and religions, depending on whether they are Christian, Muslim, Jew or any other. She argues that women theologians believe in a particular God's word for women and they stand by it to proclaim freedom and renew their experience with God, but not a way to reject classical theology. This is how she puts it:

\begin{abstract}
... le Cercle est le lieu où les femmes concernées peuvent faire une théologie basée sur leur religion, leur culture et leurs expériences sociales. C'est une théologie qui ne se fait pas seulement dans la tête mais aussi et surtout dans le cœur et dans le ventre [... ] C'est ainsi que nous avons appris dès le départ à aborder toutes nos difficultés en tant qu'africaines tout simplement. Nous avons compris d'emblée que la libération de la femme africaine concerne toute femme vivant sur le continent (chrétienne, musulmane, juivne, animiste) et que Dieu a une parole spécifique pour nous. Nous faisons de la théologie contextuelle. Elle est basée sur notre expérience de Dieu au quotidien. (Yinda \& Mbuyi Beya 2007:163-164)
\end{abstract}

At the heart of the Circle of Concerned Women Theologians, women such as Kasa Dovi in Togo and Helene Yinda in Cameroon made preachings and biblical studies an opportunity to talk about existential problems, with new instruments of popular reading different from scientific reading. In her book, Femmes Africaines [Women in Africa], Helene Yinda (2002) indicates:

\begin{abstract}
dans les discussions et le partage d'expériences entre nous, dans de multiples rencontres, colloques et séminaires de formations que nous avons organisés au sein de notre Cercle des théologiennes africaines engagées; dans l'immense somme d'informations dont nous disposons après la décennie des Eglises en solidarité avec les femmes' (1988-1998) organisée par le Conseil Ecuménique des Eglises (COE), nous savons en tant que théologiennes qu'il est de notre devoir de prendre la parole au nom de l'Evangile pour parler aux hommes et aux femme d'Afrique. Nous parlerons ici avec tout notre être: $\mathrm{du}$ fin fond de ce que nous avons vécu au cœur de nos églises, comme des témoins d'une situation qui a mûri dans nos consciences et qui nous engage à réfléchir et à agir autrement. (p. 6)
\end{abstract}

In the perspective to bring the Gospel as a new speech to men and women in churches, Helene Yinda set a school for women in Yaounde (Cameroon), the school has the specificity to link theology and life, biblical reading and concrete problems. The objective is to find in the Word of God the base of relief and the power to face difficult situations of life. Without the wind of the Circle, such a school could not have existed. We would have still been thinking that theology can only be done inside classical higher institutions with university criteria. 
If I talked of the Togolese theologian Kasa Dovi, I intended to show her work of preaching in which she focused on biblical studies of the apostle Paul, as he addressed specific communities with specific problems. Today, some of Paul's visions cannot be understood if they are only related to specific issues on women of this era, 'in spirit and truth'. Just to show some examples:

- Talking about woman submission is 'in spirit and truth' the expression of love and enjoyment of marital relationship in a society of human rights and coresponsibility.

- Talking about the defence for a woman to talk in public places can be understood as Paul presented them as Prophetesses of communities. Where did women prophesise? In the bed? asked Kasa Dovi during a wonderful sermon in Lomé.

For the Togolese theologian Kasa Dovi, the main fight is based on the review of Paul's Letters related to women's situation, while the Cameroonian theologian Louise Tappa denonces the lies about a patriarchal reading of the Bible from Adam, the man from whom woman's inferiority is sacralised because she introduced the sin into the world (Yinda 2002:54).

It is a great advancement to direct preaching and theological training in a more essential perspective than academic: it is the succession of a demystified 'scientific' theology that engenders a real popular and lively theology. This is an important impact of the Circle in the French-speaking zone.

\section{Culture, tradition and modernity: The choice of intelligence}

In the history of African theology, culture always has an essential dimension because indigenous theologies and theology of identity to in-cultural theologies. The Circle of Concerned African Women Theologians is deeply committed to this dimension and one of the personalities in this domain is the theologian Musimbi Kanyoro from Kenya.

In her work on feminist cultural hermeneutics (Kanyoro 1992, 2002), she constantly uses metaphors of African traditional culture. What characterises the most in her work is the integration of women problems in a particular cultural vision: destructive creation and rebuilding creation. She puts issues of tradition and modernity of Africa into a road of difficult choices. She uses the image of a predator that smells the odour of an animal lost in a square, not knowing which road it can take. Actually, a choice must be made. Africa is like the animal that must make a decision. In any choice Africa can take, there is the risk of success or failure. What if the solution is to invent a new road?

To invent a new road, the animal is unable to do so; but human beings can. The true solution is not to react as an animal but as a intelligent being who can measure the impact of not bringing to existence the new road. In so doing, culture appears to be a quality of creating a respectful modernity of human rights in a global sense, based on purified and mastered traditional culture: right to life, right to food, right to housing, right to enjoyment, right to happiness and so on. One can decide to put these rights as a way of life and project the future.

In a more concrete manner, Musimbi Kanyoro developed a theology of critical perspicacity towards modern or traditional cultures, giving African women the possibility to read the Bible as a place for conscious choices. No more hesitation between modernity and tradition. The Bible is the tool she uses to give birth to women of critical intelligence so they can react in situations where no solution is seen in advance. This is a fundamental impact in African theology today.

\section{A theology of practical commitment}

The theological work of the Circle, which has become a reference, is the practical orientation on the main problem that weakens Africa since 1980: HIV and/or AIDS. The theologian Musa Dube from Botswana is the main personality who related culture, society, Bible and HIV infection (Dube 2004:115-140). She has shown that the problem is not only medical but anthropological and spiritual.

At the time when churches considered HIV as God's punishment, Musa Dube provided a theology of love and social responsibility to avoid discrimination, ostracism, stigmatisation towards people living with HIV (Dube 2003). She is the more sensitive theologian to this issue and she organised the fight in such a way that churches can play an important role.

Today, these issues have been spread all around and organisations such as the World Council of Churches are at the forefront of the fight. The Circle has a prominent place in organising the fight against HIV in Africa. This is proved by the fact that one of the world highest directors of Ecumenical HIV and AIDS Initiatives and Advocacy (EHAIA) is the theologian Nyambura Njoroge from Kenya. Her position shows the concrete commitment of the whole Circle into problem-centred theology among which we find HIV. Here, I refer to one of her testimony about the responsibilities at EHAIA she shared during the Pan-African Women Theologians Summit in Yaounde, which also appears in her book entitled 'Gender, justice, ministry and healing' (Njoroge 2009).

On the issue of HIV, the French zone has also being engaged in the fight. Liz Vuadi makes a parallelism between the cries for dead HIV+ African women and the cries of Rachel for her baby boy in Jeremiah 31, 15. She questions:

$\mathrm{N}^{\prime}$ allons-nous pas d'abord enterrer et continuer à pleurer ceux et celles qui sont déjà infectés? Cessant de rêver, nous sommes obligés à vivre avec, à composer avec, à faire avec si pas planifier l'avenir avec. Pour elle, la vie devrait être célébrée même à l'heure du VIH et SIDA. (Yinda \& Mbuyi Beya 2007:83-86) 
According to Liz Vuadi, when Jeremy talks about Rachel crying for her children, refusing comfort because her children could not live again, Africa do understand what sense to give to that situation, this experience is a truly lived one for its people. People living with HIV are dying every day, they make us cry. However, in Africa, life should be celebrated even related with HIV issue.

If Martin Heidegger said that each period has one and only one thought, I personally think that HIV and/or AIDS can be considered as the main problematic of the 20th century. I strongly re-affirmed that HIV and/or AIDS is not God's punishment according to the Bible and theology (Maponda 2007:151). Rather than watching from the corner of the eye, the church should play a role of responsibility bringing out a message of forgiveness and promoting ethics of responsibility (Maponda 2007:160).

\section{What to do with this inheritance?}

The four impacts that have been described show the chance for Africa (theology and churches) to have an organisation such as the Circle. It helps to see future perspectives and to commit into discussions that could have been avoided, especially as concern women empowerment and responsibility. Seeds have been planted, they germinated and were grown.

After the first and the second generations of theologians in the Circle, there is again a new generation that follows the fight through contextual Bible studies and issues on genderbased violence. There are also issues on children in war and conflict, issues on peace construction.

All the perspectives on challenges mentioned above can be fruitful if the new generations keep the spirit, the courage, determination and willingness to change things, virtues and qualities of the Circle of Concerned African Women Theologians.

Considering the progress that pioneers have made up to now, there is a fundamental question to ask: What are the roads that the Circle should follow to have a major place in Africa today and in the world, always under mutations? Is it not urgent to provide innovative ideas and to invent new ways of making theology in this context of mutations? What the Circle should be sensitive to, here and now? What are the perspectives for the future of the Circle?

Two lines can be designed:

- The first line refers to a more global and open theology, as Morin (2015) invites to 'think globally'. This means that theology on African women situation, dreams and problems should shift to a theology that considers world changes and great questions. For another word to be possible, African women theologians will face economic, political, social and cultural challenges. This will not only be towards women's demands and fight, but it will be a theology that has the capacity to deal with world issues of people, of communities, of injustice, of inequality, of stigmatisation and of atrocities seen in churches and societies. The meeting of the Executive Bureau of the Circle with Asian women fit into this objective.

Women issues are world common issues and world issues are women common issues. Therefore, the perception must change on how we deal with those issues and the orientations we give. Solutions shall be given in a planetary dimension as a contribution of Africa to the world. The future of the Circle depends on the capacity to think globally:

- The second line is related to innovation. In the present world, innovation is demanded at all levels. The theology of the Circle cannot avoid this imperative.

The idea developed here is a theology of invention, according to the sense the Congolese theologian Kinkupu gives to the expression (Kinkupu 2003). It means to give different definitions to great declarations of faith in Christian tradition. When the world shapes in its conception of man and woman, on the human identity, on the vision of love and sexuality, and when new realities such as LGBTQ (Lesbians, Gays, Bisexuals, Transsexuals et Queer) appear, all that is old should be invented a new so they can have a significant substance.

Women theologians have a great work to do if we consider all what has been said. If tradition is no longer the tool to talk about the new realities, theology will be obsolete. The Circle of Concerned African Women Theologians is my dream of innovation and a key to review the Word of God within globalisation. This will be a very long combat, which requires much strength and courage, as Hans Kung demonstrates in one of his favourite book 'Mon combat pour la liberté' (Kung 2006).

\section{Acknowledgements}

I thank Prof. Madipoane and the University of South Africa for encouraging me in writing the article as a contribution of French Zone Women Theologians. I greatly appreciate the opportunity given to me. I am also thankful to the Executive Board of the Circle of Concerned African Women Theologians for their willingness to empower women in a world where women still face challenges and violence because of sex and gender. This is the reason why it will never be enough to talk about it. A particular thank to the Founder Mercy Amba Oduyoye for the original vision of the Circle and to have believed - and made us believe - that it can be real. Thanks in particular to Preciosa Mundi for the translation of the article. May all people who intervened in one way or another to make this article possible find here a word of gratitude.

\section{Competing interests}

The author declares that she has no financial or personal relationships which may have inappropriately influenced her in writing this article. 


\section{References}

Dube, M.W., 2003, Programme d'études sur le VIH et le Sida à l'usage des Etablissements d'Enseignement Théologique d'Afrique, COE, Genève.

Dube, M.W., 2004, 'Talita Cum! A postcolonial Feminist and HIV/ AIDS Reading of Mark 5:21-43', in M.W. Dube \& M. Kanyoro (eds.), Grant me justice! HIV/AIDS Gender readings of the Bible, pp. 115-140, Orbis Books, Maryknoll.

Kanyoro, M., 2002, Introduction to feminist cultural hermeneutics: An African perspective, Sheffield Academic Press, Sheffield.

Kanyoro, M., 1992, The power we celebrate. Women's stories of faith and power, WCC, Geneva.

Kinkupu, S., 2003, Dogmes et inculturation en Afrique. Perspective d'une théologie de I'invention, Karthala, Paris.

Küng, H., 2006, Mon combat pour la liberté, Cerf, Paris.
Maponda, M., 2007, 'La femme à l'épreuve du VIH et SIDA: Réflexion théologique', in H. Yinda \& B. Mbuyi Beya (eds.), Femme, Sexe, Stigma et VIH-SIDA, pp. 151-163, Sherpa, Yaounde.

Morin, E., 2015, Penser global. L'humain et son univers, Robert Laffont et FMSH, Paris.

Njoroge, N., 2009, Gender, justice, ministry and healing: A Christian response to the HIV Pandemic, WCC, Geneva.

Oduyoye, M.A., 1995, Daughters of Anowa. African women \&partriarchy, Orbis Book, Maryknoll.

Oduyoye, M.A. \& Kanyoro, M. (eds.), 1992, The will to arise. Women, tradition and the Church in Africa, Orbis Books, Maryknoll.

Yinda, H. (ed.), 2002, Femmes africaines. Le pouvoir de transformer le monde, Sherpa, Yaoundé.

Yinda, H. \& Mbuyi Beya, B., 2007, Femme, Sexe, Stigma et VIH-SIDA, Sherpa, Yaounde. Yinda, H. \& Kä, M., 2005, Manifeste de la femme africaine, CIPCRE, Bafoussam. 